\title{
Electrochemical Properties of Oxide Scale on Steel Exposed in Saturated Calcium Hydroxide Solutions with or without Chlorides
}

\author{
Johan Ahlström (iD, ${ }^{1,2}$ Johan Tidblad, ${ }^{1}$ Luping Tang, ${ }^{2}$ \\ Bror Sederholm, ${ }^{1}$ and Simon Leijonmarck ${ }^{1}$ \\ ${ }^{1}$ Swerea KIMAB, Isafjordsgatan 28A, Kista 16440, Sweden \\ ${ }^{2}$ Division of Building Technology, Chalmers University of Technology, Gothenburg 41296, Sweden
}

Correspondence should be addressed to Johan Ahlström; johan.ahlstrom@swerea.se

Received 26 May 2018; Accepted 12 September 2018; Published 8 October 2018

Academic Editor: Flavio Deflorian

Copyright @ 2018 Johan Ahlström et al. This is an open access article distributed under the Creative Commons Attribution License, which permits unrestricted use, distribution, and reproduction in any medium, provided the original work is properly cited.

\begin{abstract}
The electrochemical properties of various iron oxide scales on steel exposed in saturated calcium hydroxide solutions were investigated. The iron oxide scales were manufactured by different heat treatments and grinding processes and characterized using $\mathrm{X}$-ray diffraction and scanning electron microscope. The electrochemical properties of the scales were assessed by measuring the corrosion potential and using electrochemical impedance spectroscopy and potentiodynamic polarization curves. It was found that wustite and magnetite are less noble compared to hematite but are more effective as cathodic surfaces. The results show that the electrochemical properties of the mill scale can be an important contributing factor in the corrosion of steel in concrete.
\end{abstract}

\section{Introduction}

Chloride induced corrosion of steel in concrete is an important deterioration mechanism for concrete structures. Many studies have been performed to determine a critical chloride threshold level and a wide range of critical chloride threshold levels has been reported [1]. One explanation of the wide range is that studies have been conducted with steel samples in an as-received condition where the mill scale from production is intact or with modified surfaces obtained by, e.g., grinding, pickling, where the steel surface is without a mill scale. Generally, it is known that the chloride threshold level is lower on surfaces with a mill scale compared to surfaces without a mill scale [2-7]. It has been reported that the mill scale has several effects on corrosion. One effect is that a remaining mill scale decreases the electrical resistance and inhibits the formation of a passive film on the steel surface in concrete $[8,9]$. Another effect is that the cathodic current is higher on a surface with a mill scale compared to a surface without mill scale [10] which affects the overall corrosion properties.
The exact mechanism the mill scale has on corrosion of steel in concrete is not fully understood. Ghods et al. [11] suggested in a microscopic study that the mill scale contains cracks which form a crevice between the mill scale and steel surface. Corrosion is then initiated through a process similar to classical crevice corrosion. The effect of different oxides on the corrosion of steel in concrete was examined by Avila-Mendoza et al. [12]. The results showed that the corrosion rate was higher on steel with red oxides, mainly hematite, compared with polished and furnace produced oxide surfaces. It was proposed that the higher corrosion rate was due to an alternative cathodic reaction: self-reduction of $\mathrm{Fe}_{2} \mathrm{O}_{3}$ to $\mathrm{Fe}_{3} \mathrm{O}_{4}$.

The mill scale originating in the steel production process consists of mainly three types of iron oxides: wustite $\mathrm{FeO}$, magnetite $\mathrm{Fe}_{3} \mathrm{O}_{4}$, and hematite $\mathrm{Fe}_{2} \mathrm{O}_{3}$ [13]. These iron oxides have different chemical and physical properties. Wustite is the least stable iron oxide and decomposes to magnetite and iron at temperatures below $570^{\circ} \mathrm{C}$. Magnetite is stable in alkaline solutions under reducing conditions and the electric conductivity is high compared with the other iron 
TABLE 1: Chemical composition of the steel bars (\% mass).

\begin{tabular}{lccccc}
\hline $\mathrm{C}$ & $\mathrm{Mn}$ & $\mathrm{P}$ & $\mathrm{S}$ & $\mathrm{N}$ & $\mathrm{Cu}$ \\
\hline 0.17 & 1.4 & 0.035 & 0.035 & 0.12 & 0.55 \\
\hline
\end{tabular}

TABLE 2: Manufacturing procedure of the different scales.

\begin{tabular}{lc}
\hline Sample name & Procedure \\
\hline Steel & Mill scaled removed; ground and degreased \\
Wustite & $850^{\circ} \mathrm{C}, 10 \mathrm{~min} \longrightarrow$ cooling to $600^{\circ} \mathrm{C} \longrightarrow$ quenched in water $\longrightarrow$ grinding to black color \\
Magnetite & $850^{\circ} \mathrm{C}, 10 \mathrm{~min} \longrightarrow$ cooling to $600^{\circ} \mathrm{C} \longrightarrow$ cooling to RT $\longrightarrow 400^{\circ} \mathrm{C}, 50$ min $\longrightarrow$ light grinding \\
Hematite & $850^{\circ} \mathrm{C}, 8 \mathrm{~min} \longrightarrow 550^{\circ} \mathrm{C}, 3$ hours \\
\hline
\end{tabular}

oxides, $100-1000 \Omega^{-1} . \mathrm{cm}^{-1}$. Hematite is stable over a wide $\mathrm{pH}$ range in oxidizing conditions and the electric conductivity is low, roughly $10^{-9} \Omega^{-1} \cdot \mathrm{cm}^{-1}$ [14]. This means that mill scales with different chemical compositions can have various effects on the corrosion of steel in concrete. The aim of this study is to produce mill scales with different chemical compositions and assess their electrochemical properties to show if electrochemistry could be a part of the mechanism the mill scale has on corrosion of steel in concrete.

\section{Materials and Methods}

2.1. Manufacturing of Oxide Scales. During annealing of steel a mill scale is formed on the steel surface which consists of three types of iron oxides. The part of the scale closest to the steel surface is dominated by wustite, $\mathrm{FeO}$, the middle part is dominated by magnetite, $\mathrm{Fe}_{3} \mathrm{O}_{4}$, and the outermost part is dominated by hematite, $\mathrm{Fe}_{2} \mathrm{O}_{3}$.

Steel samples were cut from a hot rolled plate, S235 JR (EN 10025-2:2004), to the dimensions $25 \times 25 \mathrm{~mm}$ and $2 \mathrm{~mm}$ thick. The composition of the steel can be seen in Table 1.

The mill scale on the hot rolled samples was removed by grinding with 1200 grit paper and thereafter cleaning in an ultrasonic bath for 10 minutes in 50\% ethanol and 50\% acetone. After cleaning, the steel samples were heat-treated in order to produce an oxide scale dominated by a certain iron oxide and in the following the samples are therefore named after the intended dominating oxide: wustite, magnetite, and hematite. The manufacturing procedure of the different scales can be seen in Table 2 .

Bare steel samples were made for comparison with the manufactured oxide scale samples. The original mill scale was removed by wet grinding with 600 grit paper and then rinsed in alcohol, dried, and stored in a desiccator until the start of the electrochemical experiments.

All samples, except steel which were used as a reference, were annealed at $850^{\circ} \mathrm{C}$ for $8-10$ minutes and then cooled with different rates depending on the desired oxide layer. Wustite is stable in temperatures higher than $570^{\circ} \mathrm{C}$ and decomposes to magnetite and iron below $570^{\circ} \mathrm{C}$ according to the reaction:

$$
4 \mathrm{FeO} \longrightarrow \mathrm{Fe}_{3} \mathrm{O}_{4}+\mathrm{Fe}
$$

The transformation rate is slow at room temperature and fast between $400-480^{\circ} \mathrm{C}$ [15]. To produce a wustite rich oxide layer the samples were first annealed at $850^{\circ} \mathrm{C}$ and then cooled to $600^{\circ} \mathrm{C}$ in the oven leaving the lid open. This was followed by quenching the samples in water to obtain a fast cooling rate to room temperature. In this way the samples were exposed to temperatures between $400-480^{\circ} \mathrm{C}$ for a very short time and the transformation reaction was suppressed. When the samples were quenched in water from higher temperatures than $600^{\circ} \mathrm{C}$ the oxide scale spalled of the steel surface. After cooling, the oxide surface was wet ground with 600 grit paper. During wet grinding the water turned red/orange indicating the removal of hematite from the sample. With further grinding the water turned grey which was also the color of the sample surface indicating magnetite. At the end of the grinding the water color and color of the sample turned black indicating wustite. At this point the grinding was stopped and the sample was rinsed with alcohol and dried with a hair dryer. All samples were then stored in a desiccator.

To produce a magnetite-rich scale the samples were annealed and then cooled in the oven to $600^{\circ} \mathrm{C}$ leaving the lid open, followed by air cooling to room temperature. This was followed by a second heat treatment at $400^{\circ} \mathrm{C}$ for 50 minutes. $400^{\circ} \mathrm{C}$ was chosen to obtain a fast transformation rate of wustite to magnetite and iron. After the heat treatment the samples were wet ground until the red water color disappeared as described earlier indicating that magnetite was the dominating oxide in the oxide scale. The samples were then rinsed in alcohol, dried, and stored in a desiccator.

To produce a hematite rich layer, the samples were annealed at two temperatures. The first annealing temperature was at $850^{\circ} \mathrm{C}$ as for the other samples and then the temperature was lowered to $550^{\circ} \mathrm{C}$ and the second heat treatment was performed for 3 hours. The relatively long heat treatment at $550^{\circ} \mathrm{C}$ was chosen to oxidize the magnetite without obtaining thick scales. After the second heat treatment, the samples were air cooled and rinsed with alcohol and dried before being stored in a desiccator.

To control if the desired oxides had been formed on the steel samples, the samples were analyzed with X-ray diffraction (XRD) and scanning electron microscope in combination with electron backscatter diffraction (SEM/EBSD). The XRD measurements were performed on crushed oxide scales with a Bruker D8 using $\mathrm{CuK}_{\alpha}$ radiation. The crushed scale was collected by hammering on the sample surface using a steel hammer. 
TABLE 3: Calculated composition from XRD spectra of the samples [\%].

\begin{tabular}{lccc}
\hline Phase & Wustite & Magnetite & Hematite \\
\hline $\mathrm{Fe}$ & - & 4 & - \\
$\mathrm{FeO}$ (wustite) & 88 & 17 & 26 \\
$\mathrm{FeO}(\mathrm{OH})$ & 9 & - & - \\
$\mathrm{Fe}_{3} \mathrm{O}_{4}$ (magnetite) & 2 & 77 & 39 \\
$\mathrm{Fe}_{2} \mathrm{O}_{3}$ (hematite) & 1 & 2 & 35 \\
\hline
\end{tabular}

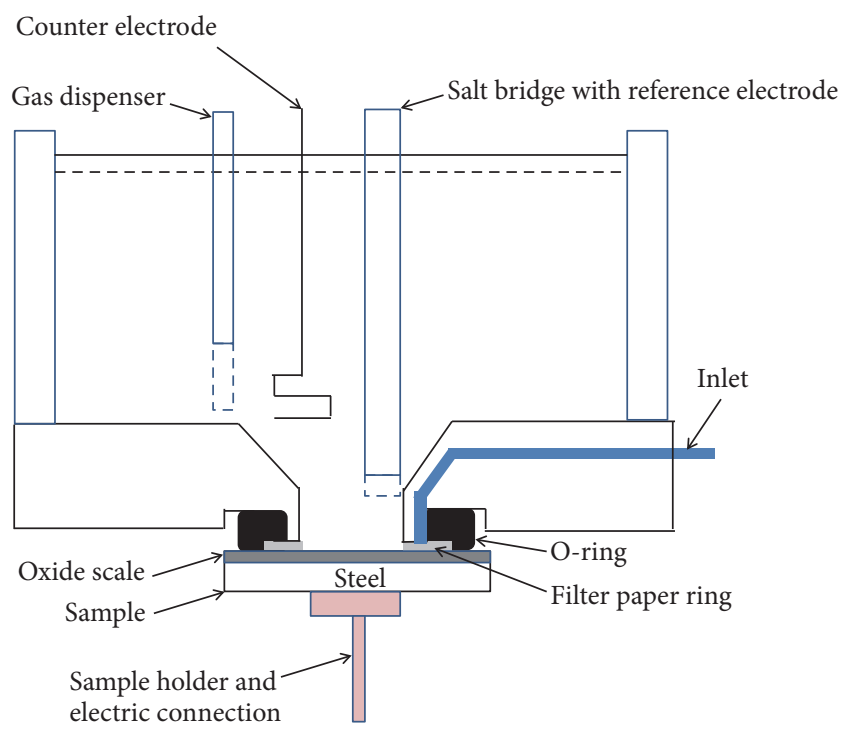

FIgURE 1: A schematic figure of the Avesta cell.

The sample preparation for the SEM/EBSD investigations were performed by first sputtering a thin gold layer onto the oxide scale surface, typically a few $\mathrm{nm}$, and thereafter applying a nickel layer, typically $2 \mu \mathrm{m}$ thick, by electrodeposition. The EBSD analyses were performed with an LEO 1530 FEGSEM equipped with an Oxford EDS/EBSD system. A cross section of the manufactured oxide scale was analyzed where the cut samples were mounted in epoxy and ground with 1200 mesh paper and polished to $1 \mu \mathrm{m}$ with diamond paste. The last step of the sample preparation was polishing in a colloidal silica suspension.

2.2. Electrochemical Measurements. The electrochemical experiments were performed using an Avesta cell in order to avoid crevice corrosion [16]; see Figure 1. The circular exposed sample area was $1 \mathrm{~cm}^{2}$. The Avesta cell has an inlet where a saturated $\mathrm{Ca}(\mathrm{OH})_{2}$ solution is pumped into the main cell via a filter paper that is put around the sample area. In this way there is no oxygen depletion at the edges of the exposed sample area and crevice corrosion can therefore be avoided.

The main cell was filled with $120 \mathrm{ml}$ of either saturated $\mathrm{Ca}(\mathrm{OH})_{2}$ solution or a saturated $\mathrm{Ca}(\mathrm{OH})_{2}$ solution with $0.6 \mathrm{M} \mathrm{Cl}^{-}$added as $\mathrm{NaCl}$. The pumping rate of the saturated $\mathrm{Ca}(\mathrm{OH})_{2}$ into the cell was $3.3 \mathrm{ml} / \mathrm{h}$ which means that when the main cell was filled with the chloride containing solution the chloride concentration was slowly diluted during the experiments. The reason why a chloride free solution was pumped into the cell was to eliminate problems with corrosion which would occur on steel samples below the filter paper when a chloride containing solution was used. To avoid chloride concentration gradients in the cell, air was bubbled into the cell through a gas dispenser.

The reference electrode used was a double junction $\mathrm{Ag} / \mathrm{AgCl}$ sat $\mathrm{KCl}$ electrode immersed in a salt bridge with a saturated $\mathrm{K}_{2} \mathrm{SO}_{4}$ solution. A salt bridge was used as the $\mathrm{Ag} / \mathrm{AgCl}$ electrode can become inaccurate in high $\mathrm{pH}$ solutions. A platinum wire was used as counter electrode. The measurements were performed using a Solartron 1286 potentiostat and a Solartron 1255 frequency analyzer.

The following procedure was performed for each sample. The open cell potential (OCP) was measured for $10 \mathrm{~min}$ utes. Electrochemical impedance spectroscopy (EIS) measurements were then performed in the frequency interval $10^{5}-10^{-3} \mathrm{~Hz}$ and amplitude $\pm 20 \mathrm{mV}$ vs. OCP. Finally, a potentiodynamic polarization scan was made in either anodic or cathodic direction with the OCP as starting point. The scan rate was $0.2 \mathrm{mV}$ per second and the samples were polarized to $0.8 \mathrm{~V}$ in the anodic direction and to $-0.8 \mathrm{~V}$ in the cathodic direction. In total 16 samples (4 types of oxides exposed in saturated $\mathrm{Ca}(\mathrm{OH})_{2}$ water with either 0 or $0.6 \mathrm{M} \mathrm{NaCl}$ and polarized in either anodic or cathodic direction) were tested.

\section{Results and Discussion}

\subsection{Analysis of Manufactured Oxide Scales}

3.1.1. $X R D$. The manufactured oxide scales were analyzed with XRD and SEM/EBSD (SEM in combination with electron backscatter diffraction). The calculated composition from the XRD intensity spectra of crushed oxide scales can be seen in Table 3. According to the XRD results, the sample named wustite consisted of mostly wustite with minor content of hematite, magnetite, and $\mathrm{FeO}(\mathrm{OH})$. The $\mathrm{FeO}(\mathrm{OH})$ may have been formed due to oxidation of wustite in air before measurement. The sample named magnetite consisted of mostly magnetite, a small amount of wustite, and minor amount of iron and hematite. Iron is found in the mill scale since wustite transforms into magnetite and iron. According to the $\mathrm{XRD}$ results, the hematite sample consisted of approximately $35 \%$ hematite. Hematite is formed by oxidation of magnetite which is a relatively slow reaction compared to formation of wustite and magnetite at $850^{\circ} \mathrm{C}$. If crushing of the oxide scale is incomplete then large flakes with hematite 


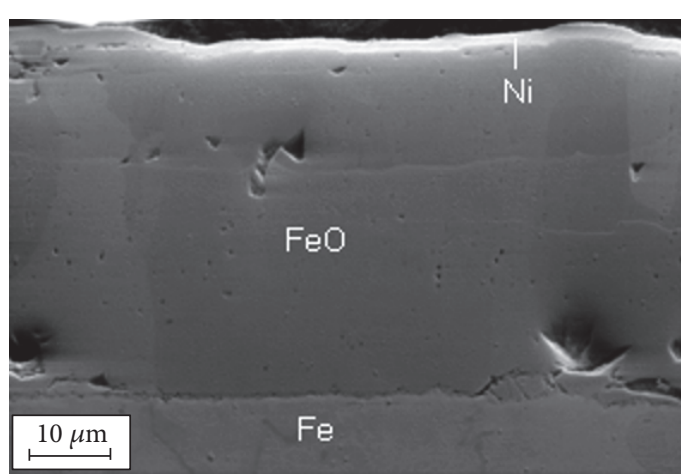

(a)

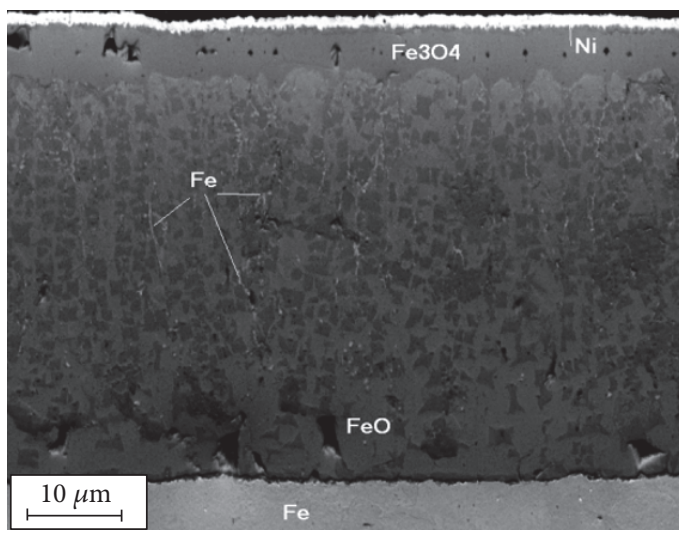

(c)

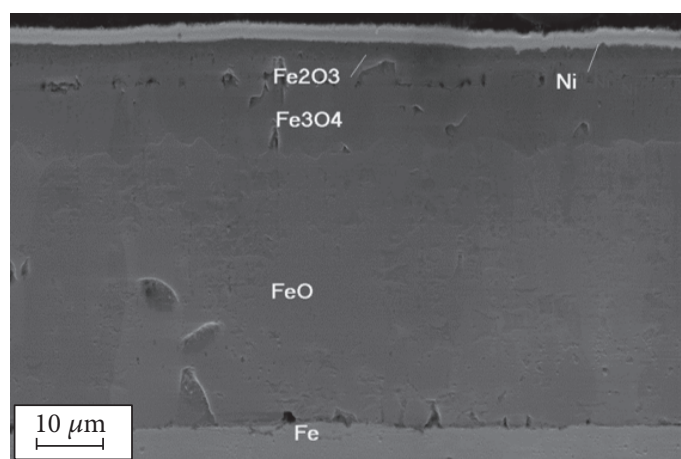

(e)

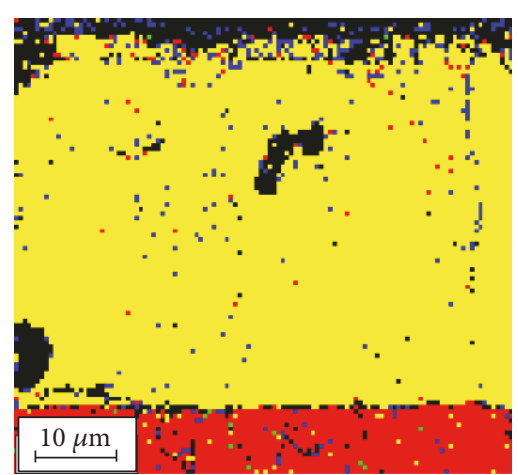

(b)

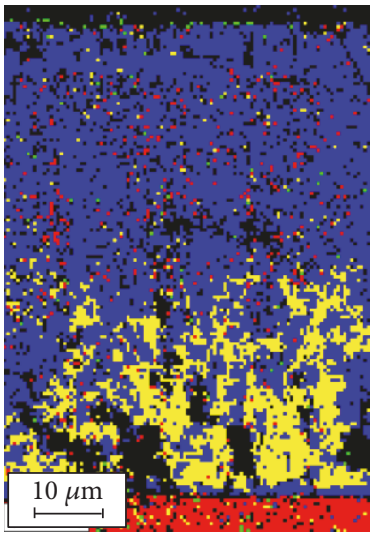

$\begin{array}{ll}\text { Hematite } & \square \text { Wustite } \\ \text { Magnetite } & \square \text { Iron }\end{array}$

(d)

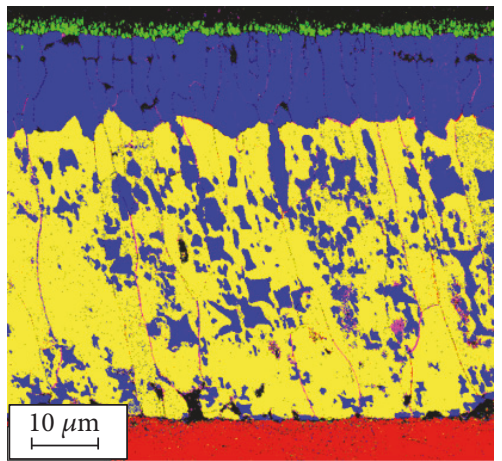

(f)

FIGURE 2: SEM images (black and white) and EBSD phase maps (color) on cross sections on the different oxide scale samples where a and b are on wustite, $c$ and $d$ are on magnetite, and $e$ and $f$ are on hematite.

on the surface will result in a positive bias in the XRD hematite signal. Therefore, it is possible that the hematite content is lower than $35 \%$. However, what is important is that hematite is located on the surface (see SEM/EBSD below), influencing the electrochemical properties of the sample.

There is a fourth iron oxide, maghemite $\gamma-\mathrm{Fe}_{2} \mathrm{O}_{3}$, which is formed by oxidation of magnetite. Magnetite and maghemite have a very similar crystal structure and are therefore very difficult to distinguish from each other with diffraction based analysis. In a study by Cook, the mill scale was assessed with Mössbauer spectroscopy which is a technique that can measure maghemite and found that the mill scale did not contain maghemite [17].

3.1.2. SEM/EBSD. One cross section sample of each oxide scale type was analyzed with SEM (in black and white) and EBSD (in color); see Figure 2. Generally, a nickel layer is seen on top of the oxide scales in the SEM figures which are not shown in the EBSD figures. The underlying steel is seen at the bottom of the figures. Figure 2(a) shows a SEM 
TABLE 4: Corrosion potential vs. $\mathrm{Ag} / \mathrm{AgCl}$ sat. $\mathrm{KCl}[\mathrm{mV}]$ : average value of two samples during 10 minutes.

\begin{tabular}{lcccc}
\hline Solution & Steel & Wustite & Magnetite & Hematite \\
\hline sat. $\mathrm{Ca}(\mathrm{OH})_{2}, 0 \mathrm{M} \mathrm{Cl}$ & -180 & -186 & -101 & 80 \\
sat. $\mathrm{Ca}(\mathrm{OH})_{2}, 0.6 \mathrm{M} \mathrm{Cl}$ & -440 & -183 & -217 & 2 \\
\hline
\end{tabular}

image of a cross section of the wustite sample where the oxide layer was measured to be approximately $50 \mu \mathrm{m}$ thick consisting of columnar grains. Figure 2(b) is an EBSD phase map over a cross section of the wustite sample where wustite is the dominating oxide from the bulk steel to the outermost surface, which is in agreement with the XRD results.

SEM and EBSD images of a cross section of the magnetite sample can be seen in Figures 2(c) and 2(d), respectively. The thickness of the scale was measured to be approximately 70 $\mu \mathrm{m}$. Small light dots can be seen in the SEM image and red dots in the EBSD figure within the oxide scale which is iron formed when wustite has transformed to magnetite and iron. Magnetite is the dominating oxide in the scale which is in agreement with the XRD results. Wustite is seen close to the steel surface. Traces of hematite at the top of the oxide scale indicate that hematite has not been completely removed in the grinding process. However, magnetite is the dominating oxide at the outermost surface of the sample.

SEM and EBSD images of a cross section of the hematite sample can be seen in Figures 2(e) and 2(f), respectively. The thickness of the scale was measured to be approximately $60 \mu \mathrm{m}$ (between the top nickel layer and the bottom steel surface). In the EBSD figure, a mixture of wustite and magnetite is seen above the steel and a magnetite layer on top of the mixture. The hematite layer at the outermost surface was measured to be approximately $2 \mu \mathrm{m}$ thick. The relatively thin hematite layer confirms the relatively low proportion of $\mathrm{Fe}_{2} \mathrm{O}_{3}$ in the XRD result which was taken from the powder of mixed layers. Because it is the outermost part of the scale that will have the most exposure to solution during the electrochemical experiments, this layer of hematite, even though very thin, is regarded as a representative sample of hematite.

\subsection{Electrochemical Measurements}

3.2.1. Open Cell Potential (OCP). The OCP was measured for 10 minutes to investigate the corrosion potentials of the samples and the average potential of two samples can be seen in Table 4. The scatter of values between each sample type is approximately in relation to the start potential of each sample type for the test of anodic and cathodic potentiodynamic potential (PDP) as will be shown later in Figures 7 and 8 . The steel and wustite samples had the least noble potential measured in the calcium hydroxide solution followed by magnetite. The hematite sample had the noblest potential.

In the solution containing chlorides the steel sample had a relatively large potential drop of approximately $250 \mathrm{mV}$ lower than in the solution without chlorides. The potential difference of the iron oxides measured in the two solutions differed by approximately $100 \mathrm{mV}$. The steel sample had the least noble potential followed by magnetite and the wustite. The hematite sample had the noblest potential. The magnetite-rich sample contained iron particles which may lower the corrosion potential in the chloride containing solution if the iron particles are exposed to the solution.

Theoretically, if a steel surface with mill scale is connected to a steel surface without mill scale, the steel surface would act as an anode and the mill scale as a cathode. It is likely that this galvanic cell would affect the passivation behavior of the steel, especially in a chloride containing solution where the potential difference in this study is measured to be about $440 \mathrm{mV}$ between steel and hematite. The distinctly different potentials of the oxide, as compared to the raw steel surface, also indicate that the oxides are relatively pore-free.

Avila-Mendoza et al. [12] compared the corrosion potential for two types of steel samples embedded in mortar, one oxidized at $800^{\circ} \mathrm{C}$ for 20 seconds and another mirror polished. They found that the corrosion potential for the oxide samples was generally more positive than that for the oxide free samples when exposed in various solutions. This is in agreement with the results in this study. In a number of papers $[2,10,18,19]$ the corrosion potentials were compared between "as-received" samples and oxide free samples exposed in alkaline solution or embedded in concrete. Akhoondan and Sagues [10] found that the measured corrosion potentials were nobler for samples in an as-received condition than those for oxide free samples whereas the others $[2,18,19]$ found that the oxide free samples had nobler potentials than the "as-received" samples. The different results may be explained by different exposure conditions and that the oxide scale in as-received condition differs between studies. It is likely that the oxide scale is relatively free from cracks in studies where the corrosion potential was nobler than oxide free samples and that the oxide scale contained many cracks in studies where the potential was less noble. If the scale contains many cracks it is possible that corrosion is initiated due to a galvanic effect by the oxide layer which lowers the corrosion potential. Unfortunately, the oxide layer is seldom characterized in terms of number of cracks, thickness and composition, which makes it more difficult to explain any effects of the oxide layer and differences between studies.

3.2.2. Electrochemical Impedance Spectroscopy. A representative Bode plot of each sample type, obtained from electrochemical impedance spectroscopy (EIS) measurements, can be seen in Figure 3, where samples were exposed in saturated $\mathrm{Ca}(\mathrm{OH})_{2}$ solution, and in Figure 4 where samples were exposed to a chloride containing $\mathrm{Ca}(\mathrm{OH})_{2}$ solution. In the solution without chlorides wustite had the lowest impedance at $1 \mathrm{mHz}$, since wustite is the least stable oxide and it is possible that oxidation of wustite was ongoing. Steel, magnetite, and hematite all had high impedances at 1 
TABLE 5: Average total impedance of two samples at $1 \mathrm{mHz}\left[10^{6} \mathrm{Ohm} . \mathrm{cm}^{2}\right]$.

\begin{tabular}{lcccc}
\hline Solution & Steel & Wustite & Magnetite & Hematite \\
\hline sat. $\mathrm{Ca}(\mathrm{OH})_{2}, 0 \mathrm{M} \mathrm{Cl}$ & 0.9 & 0.15 & 1.8 & 1.8 \\
sat. $\mathrm{Ca}(\mathrm{OH})_{2}, 0.6 \mathrm{M} \mathrm{Cl}$ & 0.015 & 0.3 & 0.7 & 1.9 \\
\hline
\end{tabular}
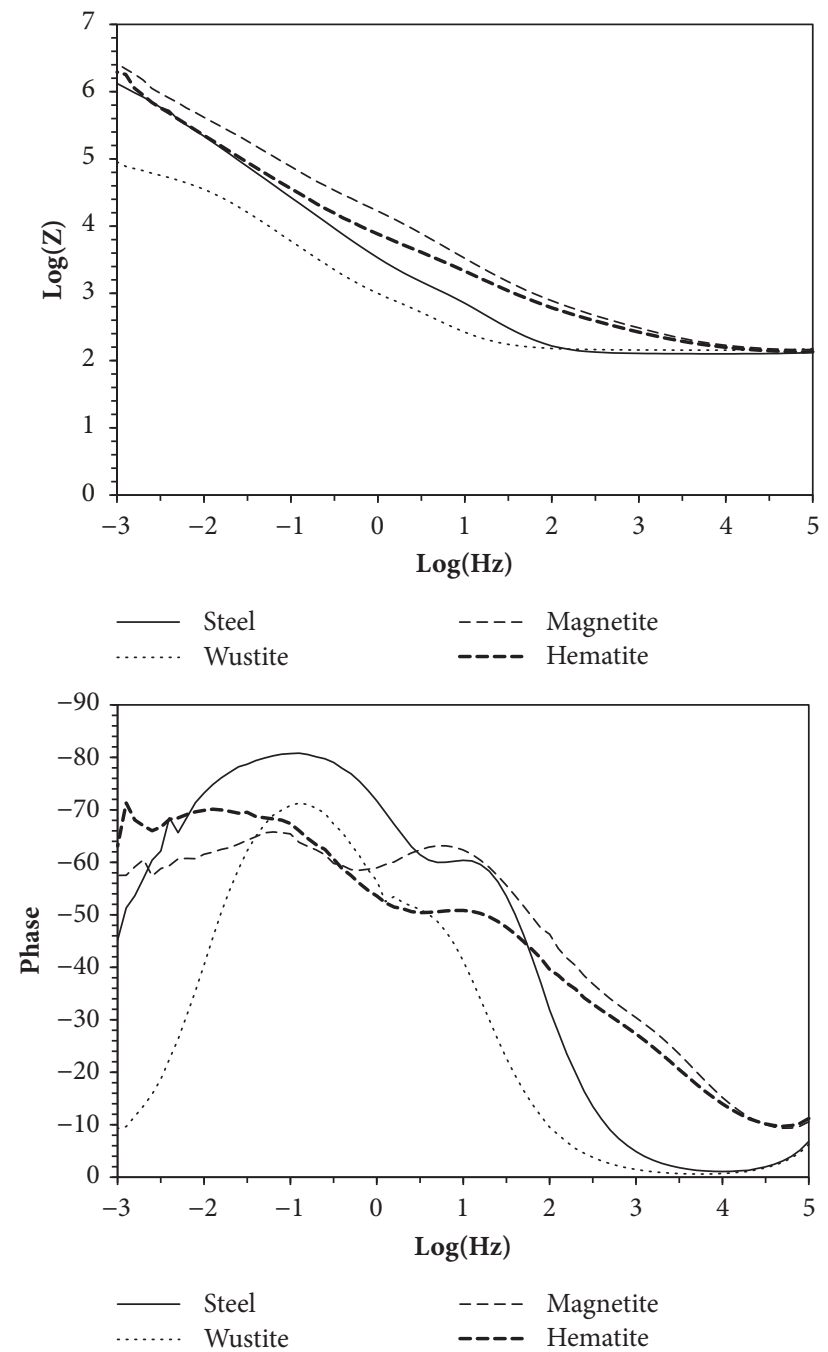

FIgURE 3: Example of Bode plots obtained in a sat. Calcium hydroxide solution.

$\mathrm{mHz}$ due to stable behavior in chloride free solution. The impedance at $1 \mathrm{mHz}$ measured in solutions with and without chlorides can be seen in Table 5. The iron oxides had at least two peaks in the Bode phase plot which may correlate with the properties of the oxide scale in the midfrequency range and the properties of the double layer in the lower frequency range. The impedance of the steel sample at $1 \mathrm{mHz}$ was relatively high and the phase angle in the Bode plot was high in a broad frequency range which is attributed to a protective passive layer. This is in accordance with [20], in which it was stated that a protective passive layer is formed during the first 10-20 minutes in concrete pore solutions.
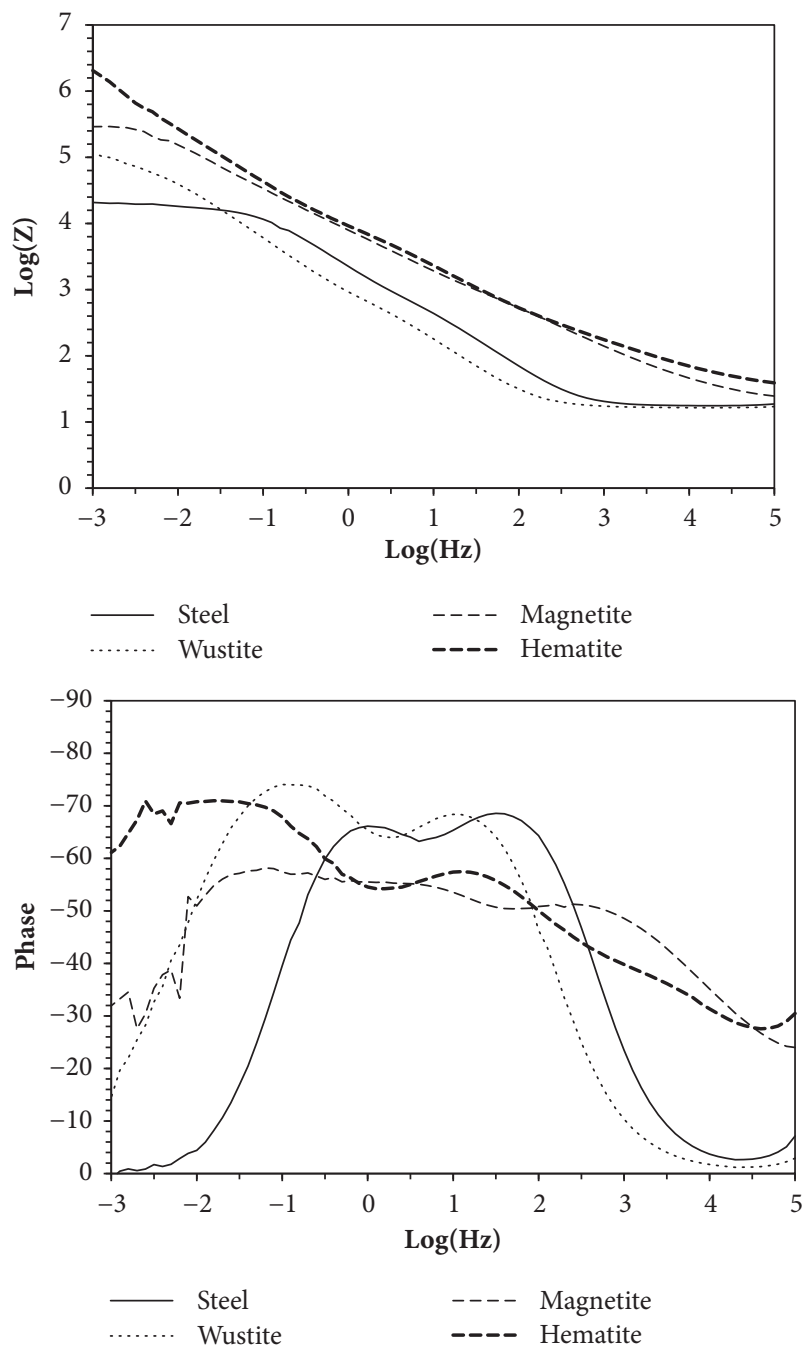

Figure 4: Example of Bode plots obtained in sat. Calcium hydroxide solution with $0.6 \mathrm{M} \mathrm{Cl}^{-}$.

In the solution containing chlorides, the iron oxides had similar Bode plots relative to the plots obtained in the solution without chlorides. The iron oxides are not strongly affected by chlorides. The impedance remained high for magnetite and hematite and relatively low for wustite. The steel sample had significantly lower impedance which is attributed to a destabilized passive layer. This is in agreement with reported studies in the literature where the impedance modulus is lower for steel exposed in chloride containing alkaline solutions compared to solutions without chlorides $[5,20,21]$.

The EIS results were further analyzed by fitting the data to the equivalent circuit in Figure 5. This equivalent circuit 
TABLE 6: Parameter data obtained from the equivalent circuit fitting for samples exposed in sat. $\mathrm{Ca}(\mathrm{OH})_{2}$. The data values are an average of two samples.

\begin{tabular}{lcccc}
\hline Parameter & Steel & Wustite & Magnetite & Hematite \\
\hline $\mathrm{CPE}_{\text {Oxide }}\left[\mu \mathrm{F}_{\mathrm{cm}}{ }^{-2}\right]$ & 30 & 110 & 9 & 20 \\
$\mathrm{R}_{\text {oxide }}\left[\mathrm{M} \Omega \cdot \mathrm{cm}^{2}\right]$ & 0.004 & 0.002 & 0.02 & 0.01 \\
$\mathrm{CPE}$ & 29 & 111 & 15 & 18 \\
$\mathrm{R}_{\mathrm{DL}}\left[\mathrm{M} \Omega \cdot \mathrm{cm}^{-2}\right]$ & 1.22 & 0.14 & 14 & 59 \\
\hline
\end{tabular}

TABLE 7: Parameter data obtained from the equivalent circuit fitting for samples exposed in sat. $\mathrm{Ca}(\mathrm{OH})_{2}$ with $0.6 \mathrm{M} \mathrm{Cl}^{-}$. The data values are an average of two samples.

\begin{tabular}{|c|c|c|c|c|c|}
\hline Parameter & & Steel & Wustite & Magnetite & Hematite \\
\hline $\mathrm{CPE}_{\text {Oxide }}$ & {$\left[\mu \mathrm{F} . \mathrm{cm}^{-2}\right]$} & 53 & 101 & 21 & 21 \\
\hline $\mathrm{R}_{\text {oxide }}$ & {$\left[\mathrm{M} \Omega . \mathrm{cm}^{2}\right]$} & $4 * 10^{-11}$ & 0.002 & 0.002 & 0.01 \\
\hline $\mathrm{CPE}_{\mathrm{DL}}$ & {$\left[\mu \mathrm{F} . \mathrm{cm}^{-2}\right]$} & 15 & 130 & 11 & 17 \\
\hline $\mathrm{R}_{\mathrm{DL}}$ & {$\left[\mathrm{M} \Omega . \mathrm{cm}^{2}\right]$} & 0.012 & 0.25 & 2 & 124 \\
\hline
\end{tabular}

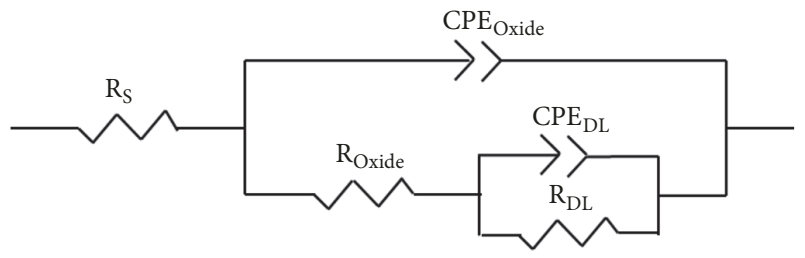

FIGURE 5: Proposed equivalent electrical circuit for fitting EIS data.

showed good fitting results with the experimental data and has been used in other studies on rebar corrosion, e.g., [22]. The capacitance of the oxide and double layer was each described by a constant phase element (CPE) which represents the inhomogeneity of the steel surface and oxide layer.

In the equivalent circuit, $R_{S}$ is the solution resistance, $\mathrm{CPE}_{\text {Oxide }}$ is the constant phase element for the oxide, $\mathrm{R}_{\text {oxide }}$ is the resistance of the oxide, $\mathrm{CPE}_{\mathrm{DL}}$ is the constant phase element for the double layer, and $\mathrm{R}_{\mathrm{DL}}$ is the resistance of the double layer.

The results from the equivalent circuit simulation can be seen in Table 6, for samples exposed to the solution without chlorides and in Table 7 for samples in the solution containing chlorides. Generally, the simulation results confirm that chlorides have a small effect on the iron oxides. The fitted data for magnetite and hematite are similar in both solutions. This is surprising since the tabulated electrical conductivity in [14] is much higher for magnetite than that for hematite and this would result in a much smaller $\mathrm{R}_{\text {oxide }}$ for magnetite compared to hematite. Theoretically, if the electrical conductivity is $10^{-9} \Omega^{-1} \cdot \mathrm{cm}^{-1}$ [14] for hematite and the hematite layer thickness is roughly $2 \mu \mathrm{m}$, this gives a resistance of $2 * 10^{5} \Omega$, and for magnetite the resistance would be approximately $6 * 10^{-5} \Omega$ using the electrical conductivity $100 \Omega^{-1} . \mathrm{cm}^{-1}$ [14] and layer thickness $70 \mu \mathrm{m}$. It is therefore possible that the magnetite sample was not ground sufficiently and had residual hematite on the sample which is confirmed by small hematite dots on top of the magnetite scale in Figure 2(d). No significant difference of the fitted values could be seen for the wustite samples exposed in either solution. For the steel samples it is clearly seen that the chloride containing solution destabilizes the passive layer, which is manifested as decreased values for $\mathrm{R}_{\text {oxide }}$ and $\mathrm{R}_{\mathrm{DL}}$ in the chloride containing solution. The capacitance increased for steel samples in the chloride containing solution, which is attributed to roughening of the corroding surface, formation of corrosion products, and formation of charged iron species [23].

Not many studies have been reported in the literature with EIS data comparing steel with mill scale and steel without mill scale. Shi et al. [9] fitted EIS data to an equivalent circuit and found that the charge transfer resistance was higher for sand-blasted samples than that for as-received samples exposed to an alkaline solution without chlorides. In chloride containing solutions the charge transfer resistance for as-received samples was higher than that for sand-blasted samples when exposed in a $0.5 \mathrm{M} \mathrm{NaCl}$ solution but lower than that for sand-blasted samples when exposed in a $1 \mathrm{M}$ $\mathrm{NaCl}$ solution. Ghods et al. [5] determined chloride threshold levels based on EIS data and found that the chloride threshold level was lower for as-received samples than that for turned and polished samples when exposed to alkaline solutions. Asreceived samples are inhomogeneous and may or may not contain cracks and defects which can explain the scatter in the reported results. The impedance modulus of the oxide scales produced in the present study is much higher compared to steel exposed to alkaline solution with chlorides since the oxide scales are protective and relatively free from cracks.

3.2.3. Potentiodynamic Polarization (PDP). All oxide scales and steel samples were assessed with PDP exposed to saturated calcium hydroxide solution with and without chlorides. Figure 6 shows the PDP curves for ground steel samples exposed to the solutions with and without chlorides. Each anodic and cathodic polarization curve started from OCP and was obtained for one sample. From the curves it can be seen that for the steel exposed to the solution without 


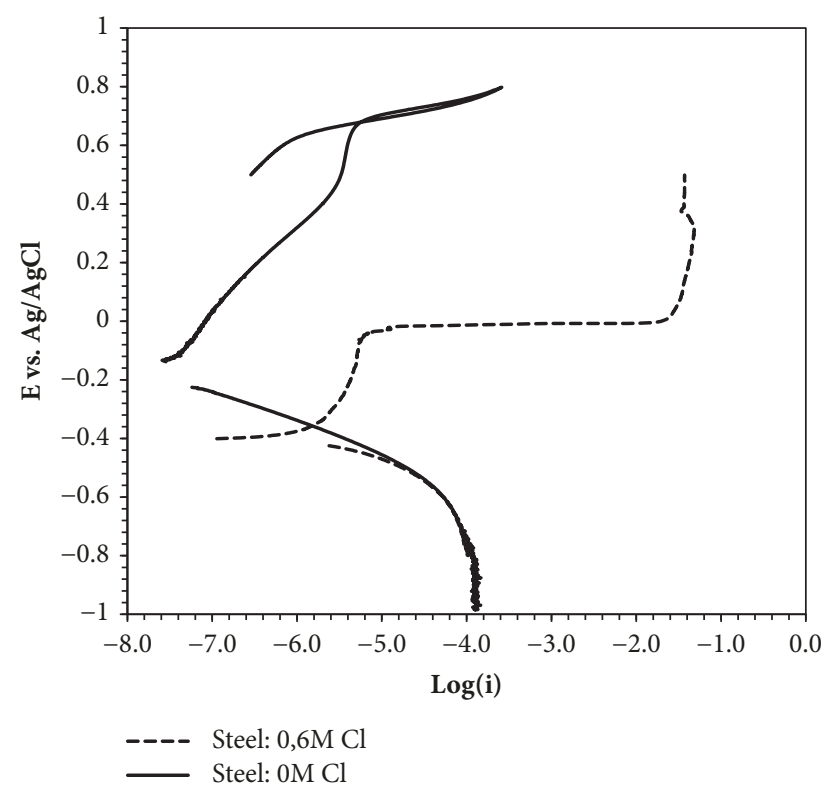

FIGURE 6: Anodic and cathodic potentiodynamic polarization curves for a steel exposed in a saturated $\mathrm{Ca}(\mathrm{OH})_{2}$ solution and a steel sample in saturated $\mathrm{Ca}(\mathrm{OH})_{2}$ solution with $0.6 \mathrm{M} \mathrm{Cl}^{-}$.

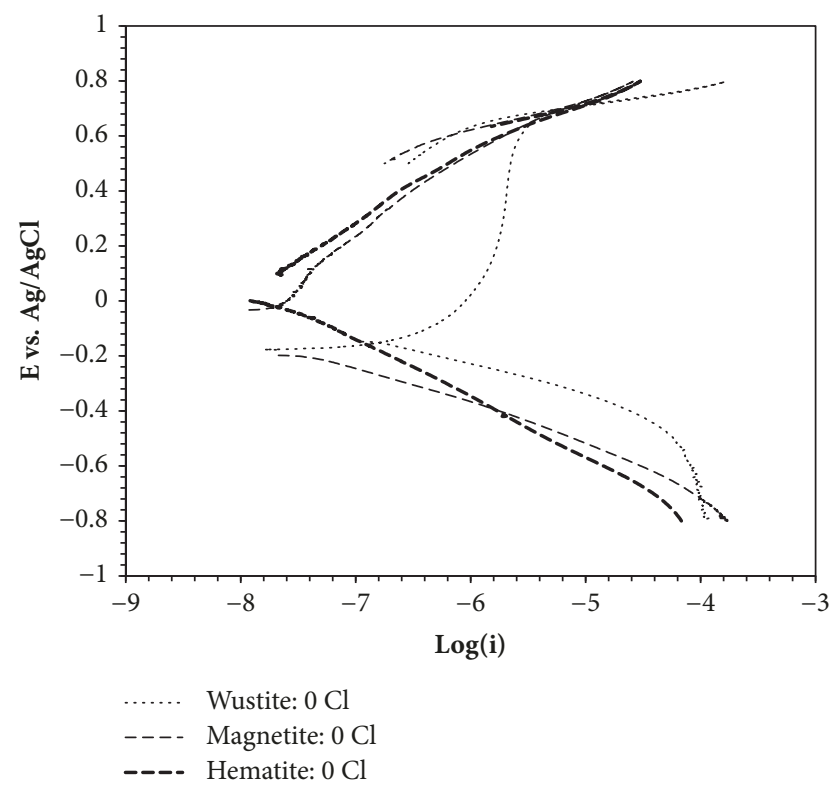

Figure 7: Anodic and cathodic potentiodynamic potential curves for the iron oxides exposed in saturated $\mathrm{Ca}(\mathrm{OH})_{2}$ solution.

chlorides the anodic current is relatively low indicating a passive behavior, whilst for the steel exposed in the solution with chlorides the anodic current increases significantly at about $0 \mathrm{mV}$ rel. $\mathrm{Ag} / \mathrm{AgCl}$, indicating pitting corrosion. These results are similar to results found in the literature, e.g., $[2,21,24]$.

The PDP curves for wustite, magnetite, and hematite exposed in saturated calcium hydroxide can be seen in Figure 7. Each anodic and cathodic polarization curve started from OCP and was obtained for one sample. The anodic

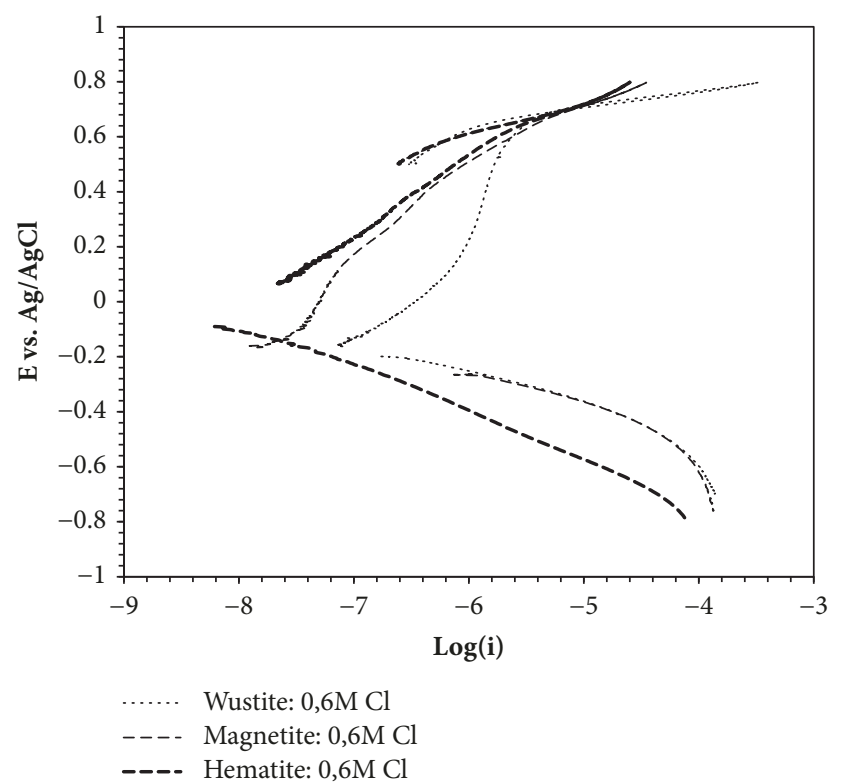

FIGURE 8: Anodic and cathodic potentiodynamic potential curves for the iron oxides exposed in saturated $\mathrm{Ca}(\mathrm{OH})_{2}$ solution with 0.6 $\mathrm{M} \mathrm{Cl}^{-}$.

current for hematite and magnetite is generally lower than that for wustite. This can be explained by the fact that these oxides are more stable than wustite. The higher anodic current for the wustite sample is also in accordance with the previous XRD results showing that the wustite sample contained $\mathrm{FeO}(\mathrm{OH})$, which means that the wustite had probably started to oxidize during the wet grinding and is easily oxidized. The cathodic current curve is a result of dissolved oxygen in the solution and possibly to some extent reduction of the oxide. Both reactions may occur simultaneously. Determining which reaction dominates is beyond the scope of this work.

The anodic polarization reversed at $0.8 \mathrm{~V}$ vs $\mathrm{Ag} / \mathrm{AgCl}$ to the cathodic direction. The reversed current was at the same level or lower than the current in the anodic direction. This means that the underlying steel is not corroding and that the increased current at $0.7 \mathrm{~V}$ is due to electrolysis of water.

Figure 8 shows the PDP curves for the iron oxides exposed in saturated calcium hydroxide with chlorides. Each anodic and cathodic polarization curve started from OCP and was obtained for one sample. The general behavior of the potential curves is similar to the behavior of the potential curves obtained in the solution without chlorides. This is also in agreement with the previous OCP and EIS results; i.e., the oxide samples do not change very much in solution with or without chlorides. The anodic current for magnetite and hematite is lower than that for wustite since wustite is oxidized at a higher rate. The cathodic current for wustite and magnetite was higher than that for hematite. This suggests that hematite has a higher resistivity and a less effective cathodic surface compared to the other oxides.

The anodic polarization reversed at $0.8 \mathrm{~V}$ vs $\mathrm{Ag} / \mathrm{AgCl}$ to the cathodic direction. The reversed current was in the 


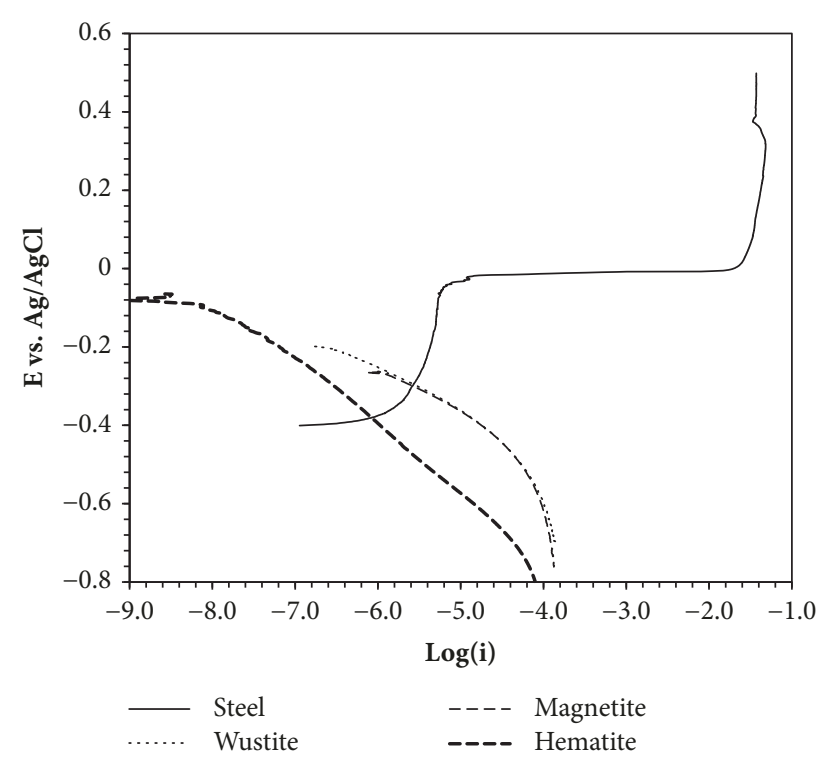

FIGURE 9: Cathodic curve for the iron oxides and an anodic curve for the steel sample.

same level or lower than the current in anodic direction. This means that the underlying steel is not corroding and is protected by the mill scale.

Figure 9 shows an overlay of previously shown selected polarization curves and the anodic polarization curve for steel and the cathodic polarization curves for the iron oxides exposed in saturated calcium hydroxide with chlorides. All iron oxides samples had a higher OCP compared to steel. The cathodic polarization curves for the iron oxides intersect with the anodic polarization curve for steel. Theoretically, this means that the steel would act as an anode and the iron oxides as cathode and the anodic current for steel would be higher if the steel was in contact with a mill scale. This can be one of the reasons why steel in an as-received condition generally has lower corrosion resistance compared to oxide free steel samples. If a small steel surface at a crack within the mill scale is exposed to a chloride containing solution, the small steel area would act as an anode and the mill scale surface would act as a cathode. The mill scale would polarize the underlying steel in the anodic direction and chlorides would migrate into the crack, continue to the steel surface, and initiate pitting corrosion.

Only a few studies have been reported in the literature where PDP curves from samples in an as-received condition have been compared with those from oxide free samples and there is a lack of quantitative information about the compositions of the mill scale in those studies. Mahalatti et al. [8] measured a higher current during anodic polarization on as-received samples compared to oxide free samples embedded in concrete with or without chlorides. The largest difference in current density was measured in chloride free concrete. One explanation may be that these as-received samples contained a large amount of wustite and therefore high anodic currents were measured. Shi et al. [9] measured a somewhat higher current during anodic polarization for as-received samples compared to oxide free samples exposed to alkaline solutions. The anodic polarization curves in the present study show that the mill scales protect the underlying steel in chloride containing solutions since these scales are relatively free from cracks. It is likely that the results from samples in an as-received condition found in the literature contain cracks where corrosion initiated on the underlying steel due to a galvanic effect as proposed in the current study.

\section{Conclusions}

In this study a combination of heat treatment and grinding processes was used to manufacture steel samples with three different synthetic mill scales: one dominated by wustite $(\mathrm{FeO})$; one dominated by magnetite $\left(\mathrm{Fe}_{3} \mathrm{O}_{4}\right)$; and one with hematite on the surface. Based on the results from electrochemical measurements the following differences can be observed:

(i) In chloride containing solutions the untreated steel sample had the least noble potential followed by samples with scales dominated by magnetite and wustite. The noblest potential was observed for the sample with hematite on the surface. The difference in potential between samples could be as high as 440 $\mathrm{mV}$.

(ii) When polarizing samples in the cathodic direction, the measured currents for the samples with scales dominated by magnetite and wustite were significantly higher than those for the sample with hematite.

In conclusion, wustite and magnetite are less noble but more effective as cathodic surfaces than hematite. The results show that the electrochemical properties of the mill scale can be an important contributing factor in the corrosion of steel in concrete.

\section{Data Availability}

The XRD data used to support the findings of this study are included within the supplementary information file. The SEM/EBSD images used to support the findings of this study are included within the article. The OPC data used to support the findings of this study are included within the article. The EIS data used to support the findings of this study are included within the article. The simulated EIS parameters used to support the findings of this study are included within the article. The PDP curves used to support the findings of this study are included within the article.

\section{Conflicts of Interest}

The authors declare that they have no conflicts of interest.

\section{Supplementary Materials}

The supplementary material files show X-ray diffraction spectra of crushed mill scale from the samples called wustite, magnetite, and hematite. (Supplementary Materials) 


\section{References}

[1] U. Angst, B. Elsener, C. K. Larsen, and Ø. Vennesland, "Critical chloride content in reinforced concrete-a review," Cement and Concrete Research, vol. 39, no. 12, pp. 1122-1138, 2009.

[2] L. Li, "Chloride corrosion threshold of reinforcing steel in alkaline solutions - Open-circuit immersion tests," Corrosion, vol. 57, no. 1, pp. 19-28, 2001.

[3] R. G. Pillai and D. Trejo, "Surface condition effects on critical chloride threshold of steel reinforcement," ACI Materials Journal, vol. 102, no. 2, pp. 103-109, 2005.

[4] M. Manera, $\varnothing$. Vennesland, and L. Bertolini, "Chloride threshold for rebar corrosion in concrete with addition of silica fume," Corrosion Science, vol. 50, no. 2, pp. 554-560, 2008.

[5] P. Ghods, O. B. Isgor, G. A. McRae, and G. P. Gu, "Electrochemical investigation of chloride-induced depassivation of black steel rebar under simulated service conditions," Corrosion Science, vol. 52, no. 5, pp. 1649-1659, 2010.

[6] T. U. Mohammed and H. Hamada, "Corrosion of steel bars in concrete with various steel surface conditions," ACI Materials Journal, vol. 103, no. 4, pp. 233-242, 2006.

[7] D. Boubitsas and L. Tang, "The influence of reinforcement steel surface condition on initiation of chloride induced corrosion," Materials and Structures, vol. 48, no. 8, pp. 2641-2658, 2015.

[8] E. Mahallati and M. Saremi, "An assessment on the mill scale effects on the electrochemical characteristics of steel bars in concrete under DC-polarization," Cement and Concrete Research, vol. 36, no. 7, pp. 1324-1329, 2006.

[9] J. Shi and J. Ming, "Influence of mill scale and rust layer on the corrosion resistance of low-alloy steel in simulated concrete pore solution," International Journal of Minerals, Metallurgy and Materials, vol. 24, no. 1, pp. 64-74, 2017.

[10] M. Akhoondan and A. A. Sagüés, "Comparative cathodic behavior of $\sim 9 \% \mathrm{Cr}$ and plain steel reinforcement in concrete," Corrosion, vol. 68, no. 4, 2012.

[11] P. Ghods, O. B. Isgor, G. A. McRae, J. Li, and G. P. Gu, "Microscopic investigation of mill scale and its proposed effect on the variability of chloride-induced depassivation of carbon steel rebar," Corrosion Science, vol. 53, no. 3, pp. 946-954, 2011.

[12] J. Avila-Mendoza, J. M. Flores, and U. C. Castillo, "Effect of superficial oxides on corrosion of steel reinforcement embedded in concrete," Corrosion, vol. 50, no. 11, pp. 879-885, 1994.

[13] X. Hu, B. Zhang, S. Chen, F. Fang, and J. Jiang, "Oxide Scale Growth on High Carbon Steel at High Temperatures," Journal of Iron and Steel Research, International, vol. 20, no. 1, pp. 47-52, 2013.

[14] R. M. Cornell and U. Schwertmann, The Iron Oxides, WileyVCH, 1996.

[15] N. Otsuka, T. Doi, Y. Hidaka et al., "In-situ measurements of isothermal wüstite transformation of thermally grown feo scale formed on 0.048 mass $\%$ fe by synchrotron radiation in air," ISIJ International, vol. 53, no. 2, pp. 286-293, 2013.

[16] R. Ovarfort, "New electrochemical cell for pitting corrosion testing," Corrosion Science, vol. 28, no. 2, pp. 135-140, 1988.

[17] D. C. Cook, "Application of Mössbauer spectroscopy to the study of corrosion," Hyperfine Interactions, vol. 153, no. 1-4, pp. 61-82, 2004.

[18] A. Poursaee and C. M. Hansson, "Reinforcing steel passivation in mortar and pore solution," Cement and Concrete Research, vol. 37, no. 7, pp. 1127-1133, 2007.
[19] D. Boubitsas and L. Tang, "The influence of reinforcement steel surface condition on initiation of chloride induced corrosion," Materials and Structures/Materiaux et Constructions, vol. 48, no. 8, pp. 2641-2658, 2015.

[20] H. B. Gunay, O. B. Isgor, and P. Ghods, "Kinetics of Passivation and Chloride-Induced Depassivation of Iron in Simulated Concrete Pore Solutions Using Electrochemical Quartz Crystal Nanobalance," Corrosion, vol. 71, no. 5, pp. 615-627, 2015.

[21] F. Zhang, J. Pan, and C. Lin, "Localized corrosion behaviour of reinforcement steel in simulated concrete pore solution," Corrosion Science, vol. 51, no. 9, pp. 2130-2138, 2009.

[22] D. A. Koleva, K. Van Breugel, J. H. W. De Wit, E. Van Westing, N. Boshkov, and A. L. A. Fraaij, "Electrochemical behavior, microstructural analysis, and morphological observations in reinforced mortar subjected to chloride ingress," Journal of The Electrochemical Society, vol. 154, no. 3, pp. E45-E56, 2007.

[23] J. Flis, H. W. Pickering, and K. Osseo-Asare, "Interpretation of impedance data for reinforcing steel in alkaline solution containing chlorides and acetates," Electrochimica Acta, vol. 43, no. 12-13, pp. 1921-1929, 1998.

[24] M. Liu, X. Cheng, X. Li, and T. J. Lu, "Corrosion behavior of low-Cr steel rebars in alkaline solutions with different $\mathrm{pH}$ in the presence of chlorides," Journal of Electroanalytical Chemistry, vol. 803, pp. 40-50, 2017. 


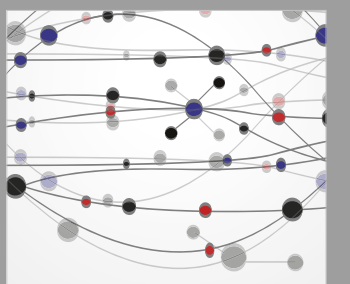

The Scientific World Journal
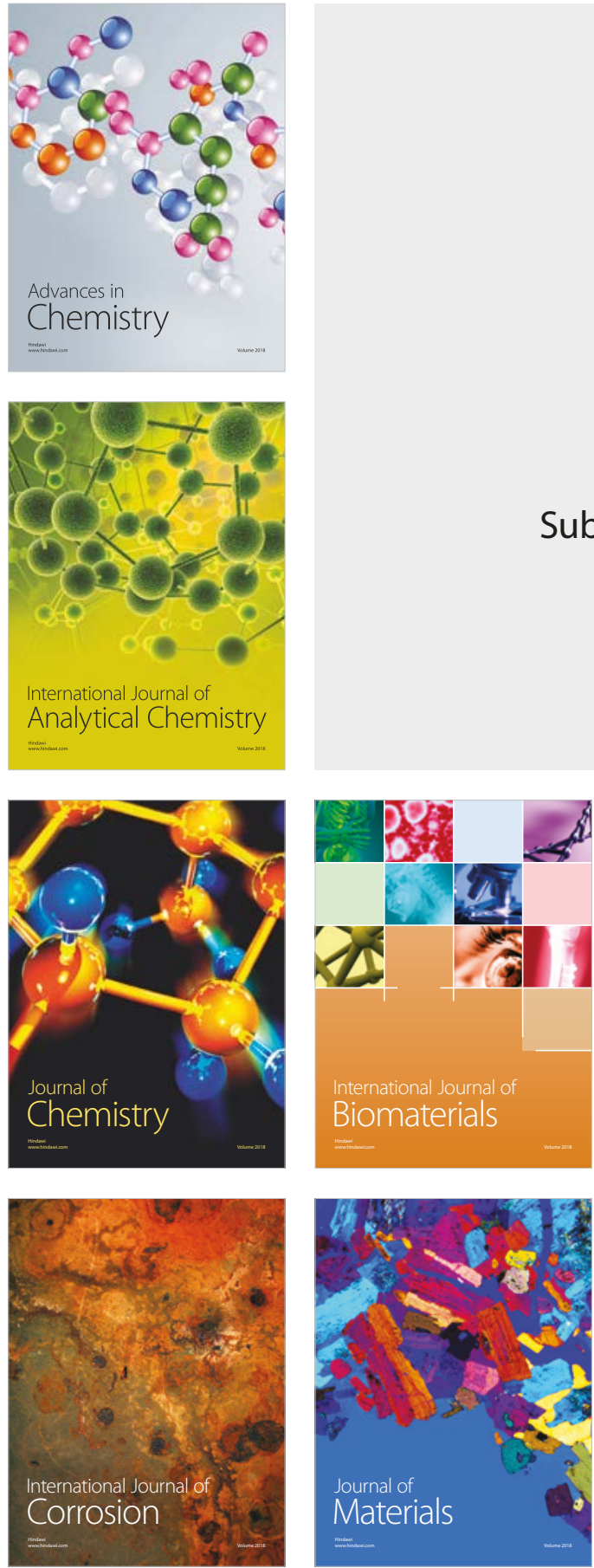

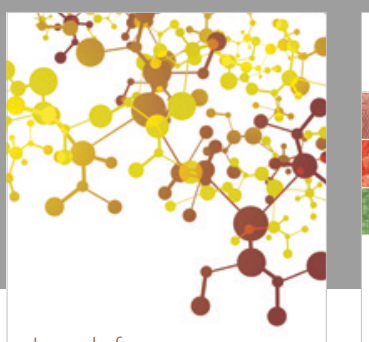

Journal of

Applied Chemistry
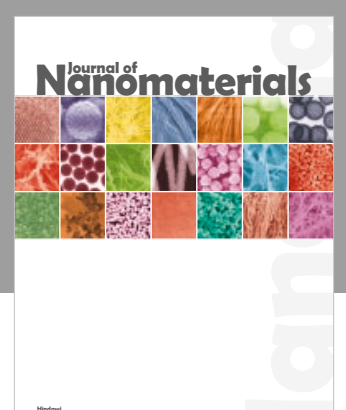

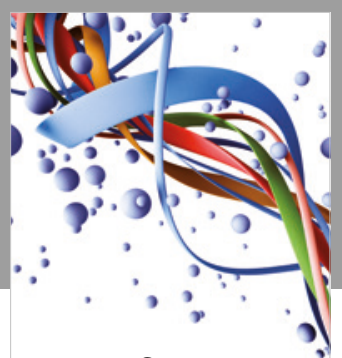

Scientifica

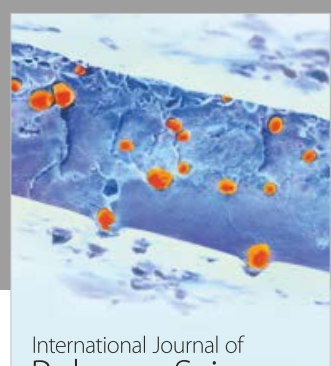

Polymer Science

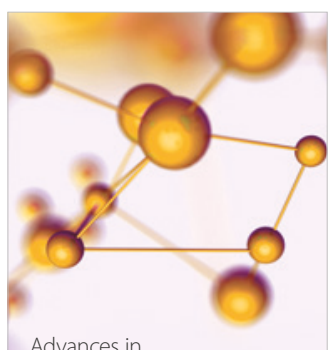

Physical Chemistry
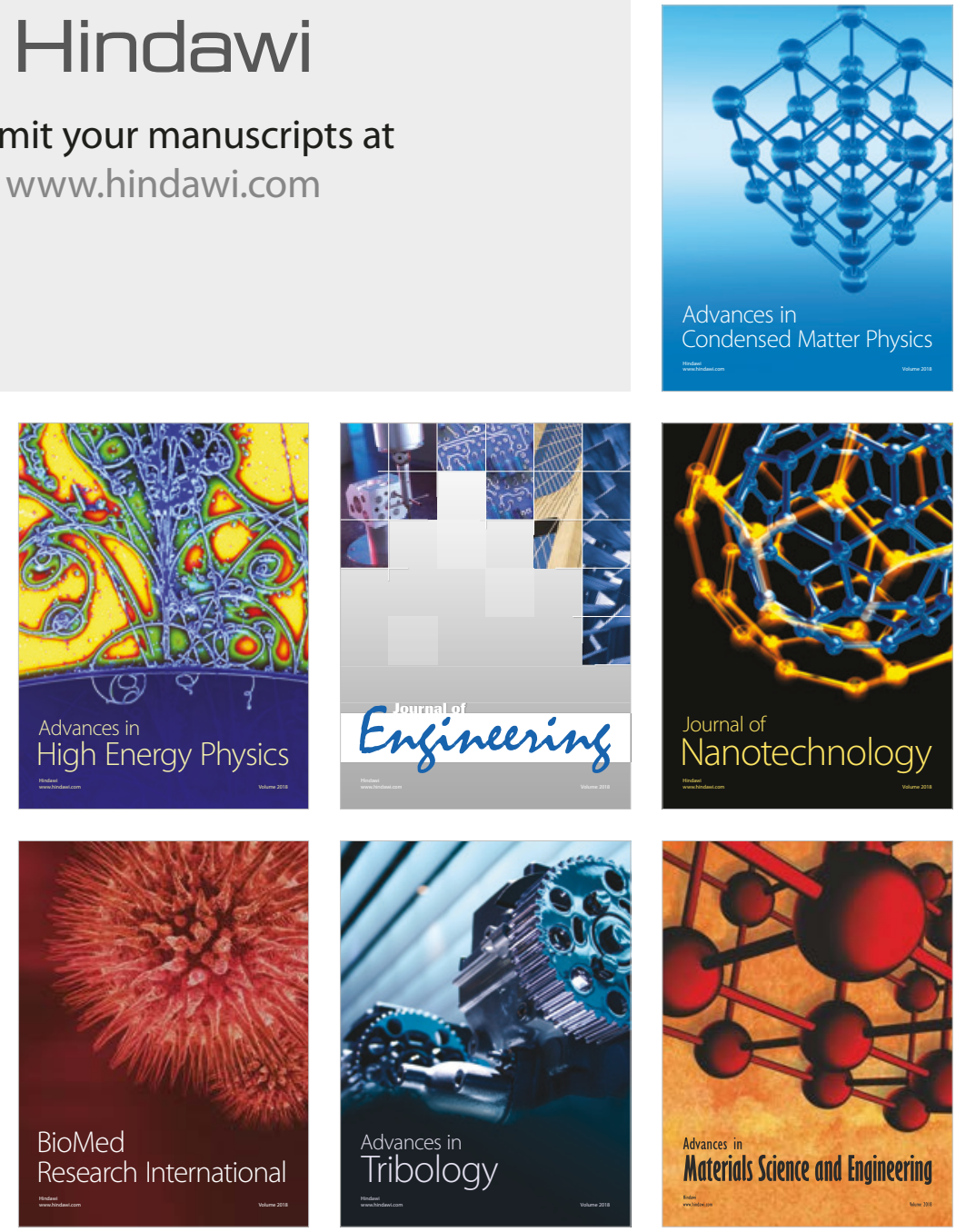